\title{
Transfer of responsibility
}

\section{Washington}

OuT of concern that the US Department of Energy (DoE)'s mandate to construct nuclear weapons conflicts with its responsibility to track the health effects of building bombs, Congress is poised to give the latter task to health agencies instead. This week, amendments transferring DoE's epidemiological functions to the Department of Health and Human Services (HHS) are expected to be tacked onto next year's Defense Department spending bill.

The move is prompted by recent disclosures of safety breaches and environmental contamination at several DoE facilities. Despite assurances by the new Secretary of Energy, James D. Watkins, that his recently unveiled ten-point plan to revamp DoE will bolster the agency's "accountability", Representative Lane Evans (Democrat, Illinois) says it still leaves the "fox guarding the chicken coop". Evans contends that DoE has suppressed studies linking exposure to low levels of radiation to cancer and other health problems, so DoE officials could keep the nuclear-weapons production machine up and running. The agency withheld epidemiological data from outside examiners, says Evans, not to protect national security, but to drop a "veil of secrecy" over the effects of its activities.

Evans's amendments would take away DoE's authority and budget to conduct epidemiological research on nuclearCHINESE STUDENTS

weapons plant workers and local residents, and give it to HHS, the agency containing the National Institutes of Health and the Centers for Disease Control. They would also set up a ninemember presidential advisory panel on radiation research that would include representatives from public interest groups, trades unions, and members from the public health departments of states with a defence nuclear facility. The results of any studies would be opened up to public scrutiny. Congressman Ron Wyden (Democrat, Oregon) plans to introduce a similar bill next month.

But Under-Secretary of Energy John C. Tuck says the health agencies already have "an extremely full plate" and that Assistant Secretary for Health James O. Mason is not keen to take over DoE's role. The National Institute for Occupational Safety and Health already sets radiation exposure standards for workers, and Congress has asked the Centers for Disease Control to evaluate whether further epidemiological studies need to be done near two of DoE's plants.

If Congress will let DoE keep its epidemiological research functions, Tuck says DoE will set up its own panel of experts from outside the agency to advise it on how to restructure its programme. DoE will also complete a \$36-million epidemiological data repository and open it up to "any qualified researcher".

Carol Ezzell

\section{Campaign in France for democracy in China}

\section{Paris}

THE presence of 6,000 journalists in Paris for the bicentenary celebrations on 14 July gave a media boost to the efforts of Chinese students campaigning for democracy in their country.

Wuer Kaixi and $\mathrm{Li} \mathrm{Lu}$, refugee leaders of the student movement, inaugurated a replica of the statue of the Goddess of Democracy which was demolished by tanks

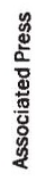

\section{IMAGE UNAVAILABLE FOR COPYRIGHT REASONS}

Chinese student leader Wuer Kaixi (left) and top intellectual dissident Yan Jiagi announced recently, in a French-television interview, their intention to set up an organization to carry on the fight for freedom in China. in Tiananmen Square on 4 June.

A solemn procession of Chinese students in mourning, which led the spectacular bicentennial parade down the Champs Elysées before 34 heads of state, was greeted by a standing ovation.

An association for the Coordination of Chinese for Democracy (CCD) was set up soon after the events in Tiananmen Square to advise the 3,000 Chinese studying in France and to maintain pressure on the Chinese government for a return to democracy. So far, says CCD president Jing Yizhong, the French government has given constructive support. Expired visas will automatically be renewed and it has been made easier for Chinese to obtain entry to France. Access to jobs has been facilitated for students unwilling to return to China, and both CCD and the French

\section{Arianespace accused}

Paris

ArianesPaCe, the consortium responsible for European commercial space launchers, has been accused of infringing international technology-transfer regulations over negotiations to sell its Viking rocket motors to Brazil. The accusation comes from US Democrat Dante Fascell, chairman of the Senate Committee on Foreign Affairs. He claims that the sale would contravene a treaty signed by the seven most industrialized nations in 1987 limiting the export of technologies which could be used to manufacture ballistic missiles (see Nature 339, 329; 1989).

The Brazilian telecommunications organization, Imbratel, has sent out a call for tenders to launch two Brasilsat satellites. As part of the deal, Arianespace has been asked to contribute technology to help Brazil develop its own small satellite launch vehicle (VLS).

In Paris, Arianespace says that the US reaction is both premature and inappropriate. No agreement can be signed without prior approval from the French government and, in any case, the technology transfer would take place in stages over a period of 15 years.

The Viking rocket, said a spokeswoman, should not come under the 1987 treaty. The rocket is destined for small launchers and uses liquid propellant, whereas ballistic missile rockets usually use solid fuel. The Viking technology has already been sold to India, said the spokeswoman.

A US Delta-2 rocket, made by McDonnellDouglas, is the main competitor with Arianespace's Ariane-4 for the Brasilsat contract. At Arianespace there is a feeling that the United States is simply making trouble to help its long-abandoned commercial launch programme get back on its feet. Peter Coles

government are discouraging students who want to return.

With a donation from couturier Yves Saint-Laurent and the Paris-Peking association, CCD has acquired an empty boutique in the centre of Paris to serve as meeting-room and headquarters. Under the slogan "We will continue", CCD says it is essential to continue to put pressure on the Chinese government, not just for Chinese students abroad but "for the whole of humanity". "When the Chinese government says it does not care about protests in the West", says Jing Yizhong, "it is lying. In fact it is very concerned about these reactions." Chinese student leaders in Paris, Cai Lin, Wuer Kaixi and Wan Dan are expected to seek asylum in the United States shortly.

Meanwhile, CCD is supporting their nomination for the Nobel Peace prize.

Peter Coles 